\title{
A NEW GENUS AND SPECIES OF DAMSELFLY FROM SOUTHERN HAITI (ODONATA)*
}

\author{
By Kenneth A. Christiansen \\ Cambridge, Mass.
}

The new species herein described was collected by Dr. Marston Bates in September, 1934, at an altitude of 4,000 feet in the Laselle Mountains of Southern Haiti. It represents a strikingly new addition to the Neotropical fauna. Every external characteristic appears to point toward a relationship with the family Synlestidx, and the penes have a remarkable resemblance to the penes of the African genus Chlorolestes; however, until the nymph has been uncovered, any family classification must remain a tentative one. Both Tillyard ${ }^{1}$ and Lieftinck ${ }^{2}$ have shown that the final court of appeal as to members of this family is the nymph. If we place this genus in the Synlestidæ, using Tillyard's divisions (op. cit.), it runs out to the subfamily Synlestinæ. This would bring the genus between the African Chlorolestes and the Australian Synlestes. The evidence of the penes and the venation seems to bear this out. If this genus is, as it appears to be, closest to Chlorolestes, this would mark another appearance of a new genus in the Neotropics whose closest ally is an African genus. ${ }^{3} \quad$ In both genera the types were captured at high altitudes.

\section{Phylolestes, new genus}

Wings long and narrow, about seven times as long as wide. Petiolation ends well before the level of the quadrangle in both wings. In the fore wings $\mathrm{Ac}^{4}$ is well distad of the level of petiolation and is opposite the midpoint between the two antenodals. In the hind wings Ac is

\footnotetext{
* Published with a grant from the Museum of Comparative Zoölogy at Harvard College.

1 Tillyard \& Fraser, Aust. Zool. 9(2), pp. 15-30, Nov. 1938.

2 Lieftinck, Treubia 17, pp. 45-61, March 1939.

3 Needham, J. G., Amer. Mus. Novitat. No. 1081, July 17, 1940.

4 Venational terms used in this paper are those of Tillyard and Fraser (op. cit.) except that Discoidal cell of Tillyard = Quadrangle.
} 
slightly distad of the level of petiolation and is closer to the second antenodal than to the first; second antenodal on a level with the arculus; quadrangle strongly acute with the proximal side as long as, or longer than, anterior side; subquadrangle separated from the wing margin with this separation more marked in the fore wing; anal bridge arises distally directly from the distal angle of the quadrangle in the hind wings, and originates slightly below the quadrangle in the fore wings; vein $\mathrm{Cu} \mathrm{P}$ swings up sharply on leaving the quadrangle; R4 plus 5 arises closer to the subnodus than to the arculus, and more than one cell before the subnodus; nodus located $\frac{1}{3}$ of the dis-
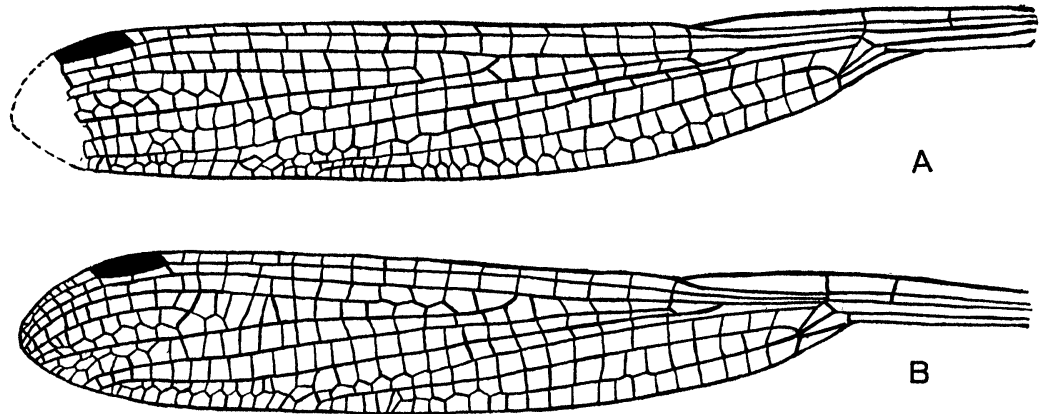

Fig. 1. Left fore (A) and hind (B) wings of Phylolestes ethelee n. g. and 1. sp., holotype. $\times 2.5$.

tance from the base to the distal end of the wing; IR3 arises at subnodus; IR2 is deflected strongly toward the stigma; at least one true ${ }^{5}$ sector between IR2 and R3, rising proximad to the level of the stigma; no oblique crossvein between R3 and IR3. Superior male abdominal appendages forcipate, inferiors rudimentary and plate-like. Penis typically Synlestine, lacking a terminal lobe and possessing a visible median spine.

The genus Phylolestes is very close in the shape of the penes to the African genus Chlorolestes; however, it may easily be separated from this genus by the venation and the shape of the inferior abdominal appendages. In

5 For the purposes of this paper a "true", sector is one which is straight for at least five cells length. 
Chlorolestes the anal bridge originates distally well down the vein descending from the quadrangle in both wings, and joins the wing margin well before reaching Ac; Ac is opposite, slightly distad, or slightly proximad of, the level of the first antenodal; the wings are petiolated to, or nearly to, the level of the quadrangle; and the inferior abdominal appendages have a heavily sclerotized spiniform area. In Phylolestes the anal bridge starts at, or very close to, the distal angle of the quadrangle and runs into Ac before reaching the wing margin; Ac is opposite the midpoint between the first and second antenodals or closer to the second antenodal; the wings are clearly not petiolated to the level of the arculus; and the inferior abdominal appendages lack any heavily sclerotized area.

The distal origin of the anal bridge is similar to a condition found in the Australian genus Synlestes, while the condition of Ac resembles that of the Oriental Megalestes; but a separation of these three genera may easily be seen by an examination of the penes and a comparison of the venation.

Genotype.-Phylolestes ethela.

\section{Phylolestes ethelæ, new species}

Synlestine in appearance with moderately slender body; coloration metallic green, bronze and black.

MALE.-Fore wing $38 \mathrm{~mm}$; hind wing $36 \mathrm{~mm}$. Head (across eyes) $7 \mathrm{~mm}$. Thorax plus prothorax $9.5 \mathrm{~mm}$. Abdomen, including the abdominal appendages, $56 \mathrm{~mm}$. Greatest diameter abdominal segment 2 (excluding appendages ) $2 \mathrm{~mm}$., of segment $6,1 \mathrm{~mm}$., and of segment 9 , $1.8 \mathrm{~mm}$. Abdominal appendages $2 \mathrm{~mm}$. long. Hind femur $6 \mathrm{~mm}$., hind tibia $6 \mathrm{~mm}$., mesothoracic femur 4.5 $\mathrm{mm}$., mesothoracic tibia $5 \mathrm{~mm}$., prothoracic femur $4 \mathrm{~mm}$., prothoracic tibia $5 \mathrm{~mm}$.

Head.-Labium obscure yellow, darker at its forward edge and cleft for more than $\frac{2}{3}$ its entire length. Labrum shiny black. Genæ and postgenæ yellow. Anteclypeus dull yellow, postclypeus metallic green. Frons and ver-

6 Measurements for thorax plus prothorax taken at greatest length from base of head to abdominal segment 1 . 
tex metallic green. Ocelli black. Occiput bronzy. Eyes (in dried specimens) brown. Basal segment of antennæ with pale ring around distal half, remainder of antennæ black. Rear of head black with metallic green reflections.

Prothorax.-Anterior lobe dull brown edged with yellow. Lateral lobes dull yellow along inferior edges. Remainder of lateral lobes and the middle lobe dull bronze. Posterior lobe ridged and slightly curved along posterior margin. Posterior margin with a central roughly lunate depressed area. Color of posterior lobe dull bronze. Mesostigmal laminæ terminate on both sides at the anterior end of the humeral suture in a low barely acute angled lobe.

Thorax.-Mesepisternum black with metallic green reflections, an indistinct brown stripe originating at the
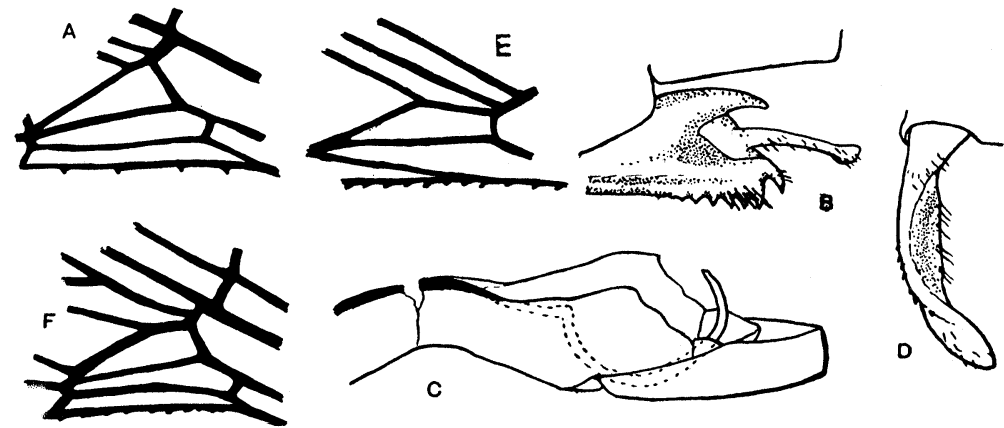

Fig. 2. A-D, Phylolestes ethela $\mathrm{n}$. g. and n. sp., (A) area of quadrangle in left fore wing of holotype; (B) right genital valve of allotype in side view; (C) penis of holotype in side view; (D) left superior abdominal appendage of holotype in dorsal view. E, Chlorolestes fasciata Burmeister, area of quadrangle in left fore wing. F, Megalestes major Selys, area of quadrangle in left fore wing. All figures enlarged.

humeral suture above and curving inward and down to the collar. A narrow yellow stripe along the humeral suture running from the mesinfræpisternum almost to the wing bases. Mesepimeron with small triangular yellow spot inferiorly tangent with mesepisternal yellow stripe. Remainder of mesepimeron brown with metallic green reflections rearward with the brown narrowing inferiorly. Metepisternum with a yellow hairline along 1st lateral suture bordered by brown. A yellow stripe extends 
along the second lateral suture. The remainder of the thorax is dull brown fading to yellow posteriorly. Antealar sinus black.

Wings.-Postnodals in fore wing 18-?, ${ }^{7}$ hind wings 16-16; R3 arises five and one-half crossveins distad of subnodus in fore wing and four to four and one-half in the hind wings. Stigma somewhat trapezoidal and three times as long as broad; proximal vein strongly angulate. The stigma covers two cells with brace vein slightly distad of the proximal end of the stigma.

Legs.-Coxæ yellow, femora and tibiæ light brown darkening towards the joints. Tarsi and claws black. Claws with a definite basal tooth. Spines short and stout on the femora; a little longer than the intervening spaces on the base of the tibia, decreasing in length toward the tarsi.

Abdomen.-The dorsum of segment one yellow basally, the remainder of the dorsum black with metallic green reflections, decreasing posteriorly. Ventrum obscure yellow. Anterior genital hamules roughly rhomboidal, yellow with black posterior edges. Superior abdominal appendages black, forcipate and simple, without any prominent spines or teeth. Inferiors rudimentary, consisting of small semicircular plates, dark brown in color.

Female.-Length of fore wing $41 \mathrm{~mm}$., hind wing 39 $\mathrm{mm}$.; abdomen $46 \mathrm{~mm}$. long and somewhat stouter than that of the male. Other measurements as in holotype.

Head.-As in holotype.

Prothorax.-Similar to the holotype except that the middle lobe is irregularly edged with black and the lateral lobes are inferiorly pruinose.

Thorax, ante-alar sinus, and mesostigmal laminæ as in holotype.

Wings.-Similar to holotype except as follows: stigma covers three cells in the fore wing and is not so strongly trapezoidal, with the proximal vein being more nearly parallel to the distal vein. Brace vein is in line with the proximal bordering vein. Stigma three times as long as

7 Right fore wing of holotype is missing. 
broad. Postnodal crossveins: fore wings, 19-18; hind wings, 15-15.

Abdomen.-Brown with metallic green reflections, blackening towards the terminal segments. Genital valves deeply serrate with the serrations recurved and increasing in size posteriorly. Ovipositor small and completely hidden by the valves.

Holotype male, allotype female, 1 broken teneral male and 1 female paratypes, vicinity of La Visite, Laselle Mts., Harti, 4,000 ft. (Marston Bates). Museum of Comparative Zoölogy, No. 27733.

Not included in the type series is another male from the neighboring La Hotte range of Southern Haiti. This specimen has several differences from the Laselle specimens; however, the penis of the La Hotte specimen was badly damaged and in the portions remaining no differences were detected between it and the holotype. The observed variance between the other features is as follows :

Holotype

Length-69 $\mathrm{mm}$.

Fore wing $33 \mathrm{~mm}$. long

Hind wing $38 \mathrm{~mm}$. long.
La Hotte male

Length-58 $\mathrm{mm}$.

Fore wing $36 \mathrm{~mm}$. long

Hind wing $34 \mathrm{~mm}$. long.

\section{Postnodal crossveins}
Fore wing 18-?
Hind wing $16-16$
Fore wing 19-18
Hind wing 14-14

The thoracic and abdominal markings are similar, but the metallic green is more pronounced in the La Hotte specimen, and the brown colors on the thorax of the holotype become metallic bronze on the La Hotte male. The abdominal appendages are similar except for a small knob on the dorso-interior surface which appears only in the La Hotte specimen.

The poor condition of the La Hotte specimen and the small amount of available material make it impossible to say whether this La Hotte male represents another species of the new genus or only the normal variation for a species living in highly isolated areas. 
I wish to extend my sincere thanks to Dr. Bequaert, Curator of Insects at the Harvard Museum of Comparative Zoölogy, for allowing me to study the material and for the aid which he furnished me during my study. I also wish to thank Mrs. Leonora K. Gloyd who read this paper and gave me many helpful suggestions about it.

Note on the Type Specimen of Bagous sellatus Leconte (Coleoptera: Curculionide).-Leconte's description of Bagous sellatus (Rhync., p. 184) mentions that the elytra have "the striæ deep, interspaces convex, first, third, and fifth more elevated, the last terminating in a large conical tuberosity, which is surrounded by a black cloud.' Blatchley (Rhync. N. E. Am., p. 236) redescribes the species and states, "sides and tips of elytra ash-gray, leaving a large, elongate triangular space black.'

In 1942, when examining the type for Prof. Tanner, the present author subjected the specimen to degreasing in order to see the structural characters more easily. At this time the black cloud or spot disappeared, indicating that it had been merely an oil spot. It had been so symmetrical that it had misled both discriminating students.

The description stands on the basis of structural characters, the specimen now being entirely ash-gray. Any further specimens placed in this species because of possessing a black spot will undoubtedly turn out to be of another species.-Floyd G. Werner, Biological Laboratories, Harvard University. 

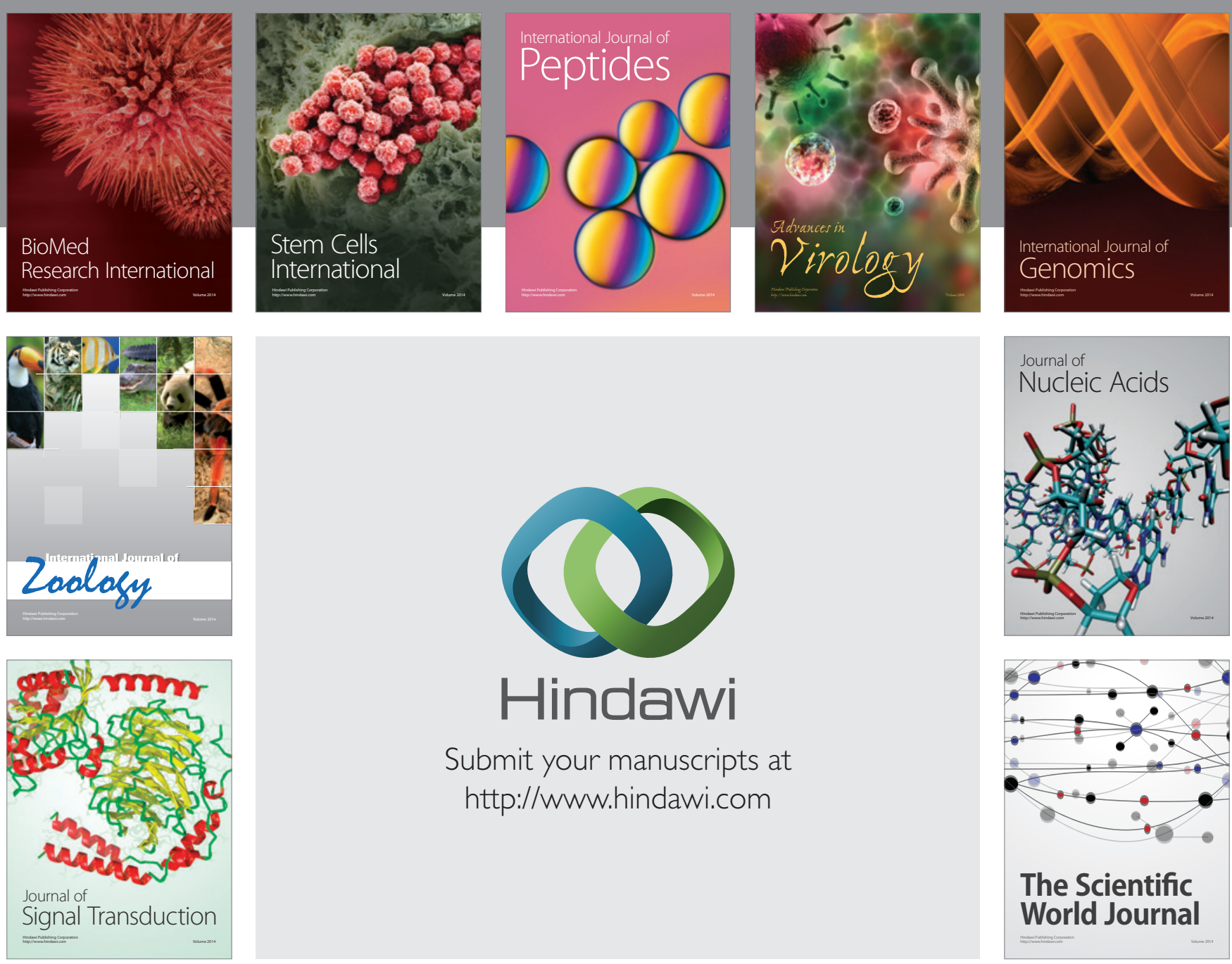

Submit your manuscripts at

http://www.hindawi.com
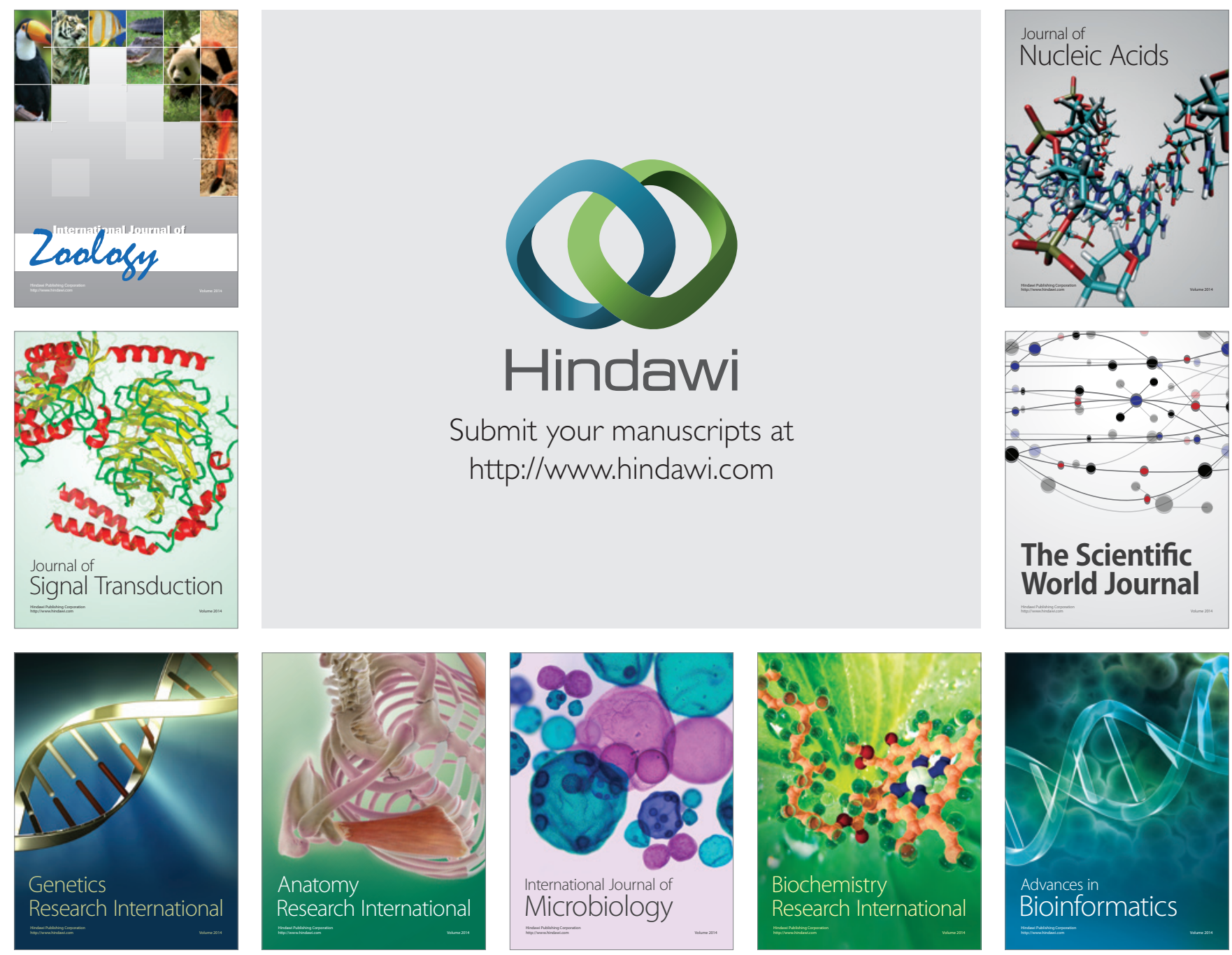

The Scientific World Journal
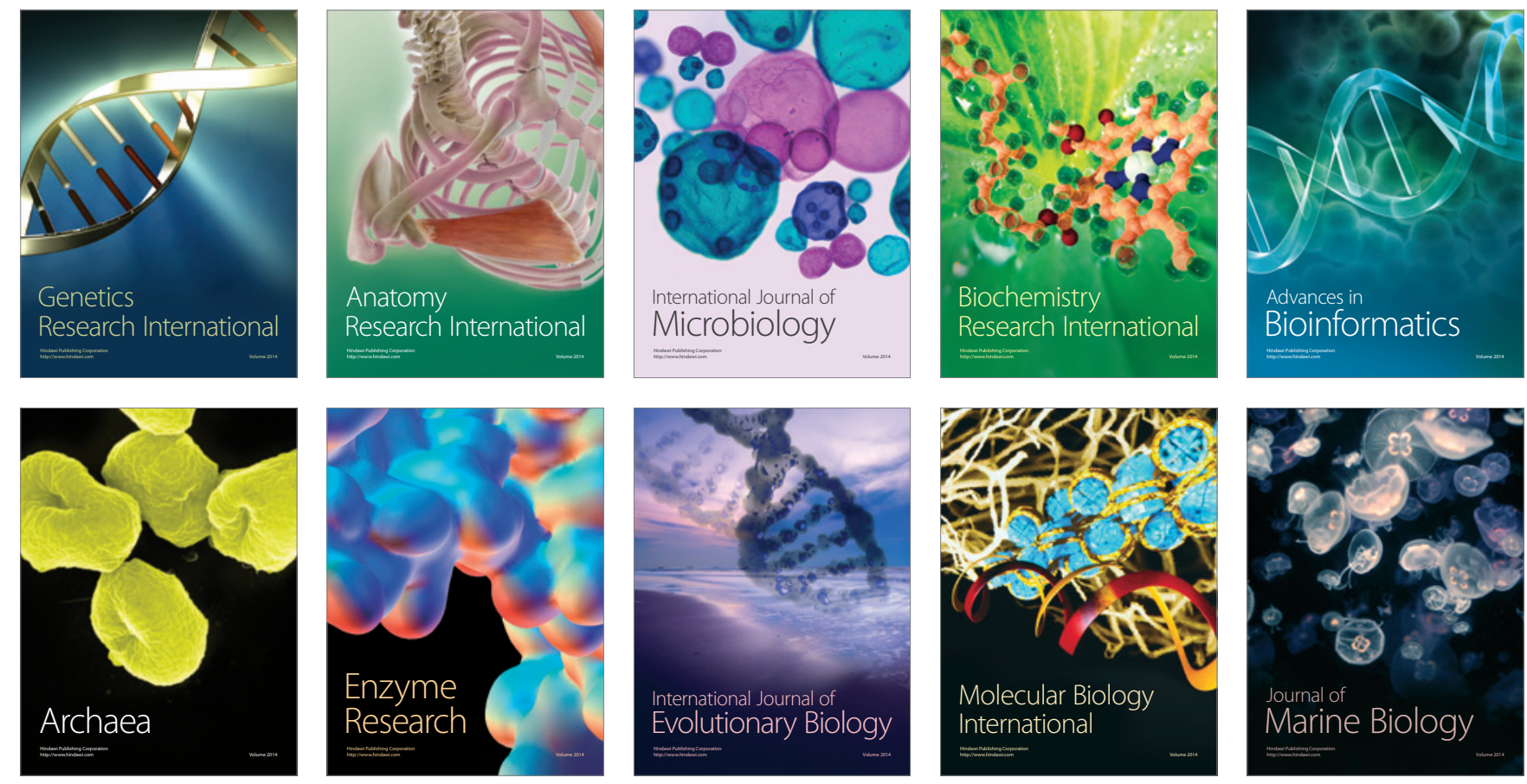